\title{
Delftia sp. LCW, a strain isolated from a constructed wetland shows novel properties for dimethylphenol isomers degradation
}

Mónica A. Vásquez-Piñeros ${ }^{1}$, Paula M. Martínez-Lavanchy ${ }^{1,2}$, Nico Jehmlich³ ${ }^{3}$ Dietmar H. Pieper ${ }^{4}$, Carlos A. Rincón', Hauke Harms ${ }^{5}$, Howard Junca ${ }^{6}$ and Hermann J. Heipieper ${ }^{1 *}$ (i)

\begin{abstract}
Background: Dimethylphenols (DMP) are toxic compounds with high environmental mobility in water and one of the main constituents of effluents from petro- and carbochemical industry. Over the last few decades, the use of constructed wetlands (CW) has been extended from domestic to industrial wastewater treatments, including petro-carbochemical effluents. In these systems, the main role during the transformation and mineralization of organic pollutants is played by microorganisms. Therefore, understanding the bacterial degradation processes of isolated strains from CWs is an important approach to further improvements of biodegradation processes in these treatment systems.

Results: In this study, bacterial isolation from a pilot scale constructed wetland fed with phenols led to the identification of Delftia sp. LCW as a DMP degrading strain. The strain was able to use the o-xylenols 3,4-DMP and 2,3-DMP as sole carbon and energy sources. In addition, 3,4-DMP provided as a co-substrate had an effect on the transformation of other four DMP isomers. Based on the detection of the genes, proteins, and the inferred phylogenetic relationships of the detected genes with other reported functional proteins, we found that the phenol hydroxylase of Delftia sp. LCW is induced by 3,4-DMP and it is responsible for the first oxidation of the aromatic ring of 3,4-, 2,3-, 2,4-, 2,5- and 3,5-DMP. The enzyme may also catalyze both monooxygenation reactions during the degradation of benzene. Proteome data led to the identification of catechol meta cleavage pathway enzymes during the growth on ortho DMP, and validated that cleavage of the aromatic rings of 2,5- and 3,5-DMPs does not result in mineralization. In addition, the tolerance of the strain to high concentrations of DMP, especially to 3,4-DMP was higher than that of other reported microorganisms from activated sludge treating phenols.
\end{abstract}

Conclusions: LCW strain was able to degraded complex aromatics compounds. DMPs and benzene are reported for the first time to be degraded by a member of Delftia genus. In addition, LCW degraded DMPs with a first oxidation of the aromatic rings by a phenol hydroxylase, followed by a further meta cleavage pathway. The higher resistance to DMP toxicity, the ability to degrade and transform DMP isomers and the origin as a rhizosphere bacterium from wastewater systems, make LCW a suitable candidate to be used in bioremediation of complex DMP mixtures in CWs systems.

Keywords: Xylenols, Biodegradation, Phenol hydroxylase, Toxicity, Constructed wetlands, Delftia sp.

\footnotetext{
* Correspondence: hermann.heipieper@ufz.de

${ }^{1}$ Helmholtz Centre for Environmental Research - UFZ, Department of

Environmental Biotechnology, Permoserstr. 15, Leipzig, Germany

Full list of author information is available at the end of the article
}

(c) The Author(s). 2018 Open Access This article is distributed under the terms of the Creative Commons Attribution 4.0 International License (http://creativecommons.org/licenses/by/4.0/), which permits unrestricted use, distribution, and reproduction in any medium, provided you give appropriate credit to the original author(s) and the source, provide a link to the Creative Commons license, and indicate if changes were made. The Creative Commons Public Domain Dedication waiver (http://creativecommons.org/publicdomain/zero/1.0/) applies to the data made available in this article, unless otherwise stated. 


\section{Background}

It is well known that the wastewater of coal conversion and coke operation processes contains high concentrations of phenolic compounds, constituting up to $80 \%$ of the total chemical oxygen demand (COD) [1]. The phenolic fraction of the this wastewater is mainly represented by phenol, cresols, resorcinols and dimethylphenols (DMP) [2], substances which are considered toxic, carcinogenic, mutagenic and teratogenic [3]. The DMPs, have shown to be even more persistent and toxic than other phenolic compounds [4] and they are often released to the environment in higher concentration than the permissible limits established $[1,5]$.

Biological treatment of phenols and their derivatives has been the main approach for their removal $[6,7]$. Biodegradation of the six DMP isomers, in pure or mixed cultures, often involves different Pseudomonas species [8-10]. Degradation of 2,6-DMP has only been reported by $\mathrm{Myco}$ bacterium sp. strain DM1 [11]. Studies aiming at the removal of DMP in a mixture with other substituted phenols in laboratory-scale sludge units have also been performed $[6,12]$. Recently, constructed wetlands (CWs) have been investigated for their potential to remove coke oven wastewater [13]. Promisingly, Schultze-Nobre et al., reported efficient removal of a mixture of three DMP-isomers (2,6-, 3,4- and 3,5-DMP) in a laboratory scale CW [14].

Complex physicochemical and biological processes in CWs include the interaction of plants, microorganism and pollutants. The main role in the transformation and mineralization of organic pollutants is played by microorganisms present in the rhizosphere, an environment suitable for highly efficient transformations of complex contaminants $[15,16]$. There is, however, little knowledge about the bacterial removal of DMP in CWs and detailed microbiological and molecular biological studies are needed to reveal the biological activities towards DMP as a basis for better management of CWs.

In this work, we aimed to isolate strains from a constructed wetland treating phenolic wastewater in order to characterize the ability to degrade DMP isomers, the toxicity tolerance toward the isomers and to reveal the genomic and proteomic mechanisms supporting the degradation. The first results indicated that Delftia sp. LCW is a versatile bacterium with novel properties to degrade DMP isomers and it could be used to enhance phenolic compounds removal in CWs.

\section{Results \\ DMP-degrading bacterium, growth and co-metabolism assays}

From the isolation trials, LCW was the strain recovered with capabilities to use DMP as sole carbon and energy source. According to its $16 \mathrm{~S}$ rRNA gene sequence, the isolate is a member of the genus Delftia. The $16 \mathrm{~S}$ rRNA gene is identical to that of Delftia sp. strain SM-1 (JN001163) and differs by only 1-2 bases from that of various Delftia acidovorans isolates (e.g. D. acidovorans SPH-1, CP000884 and D. acidovorans NBRC 14950, AB680719; 99.9\% sequence identity) but by 7-8 bases from that of Delftia tsuruhatensis and Delftia lacustris strains, including the respective type strains (D. lacustris 332 EU888308; D. tsuruhatensis T7, AB075017).

The strain was able to use 2,3-DMP and 3,4-DMP as sole carbon and energy source (Fig. $1 \mathrm{a}$ and b). Complete depletion of the isomers was observed and both substrates yielded similar bacterial biomass (Table 1 ).

In mixtures of 3,4- and 2,3-DMP the latter isomer sharply decreased the lag phase (Fig. 2a). Delftia sp. LCW was not able to grow with the other four DMP isomers. However, in the presence of 3,4-DMP, the isomers 2,5- and

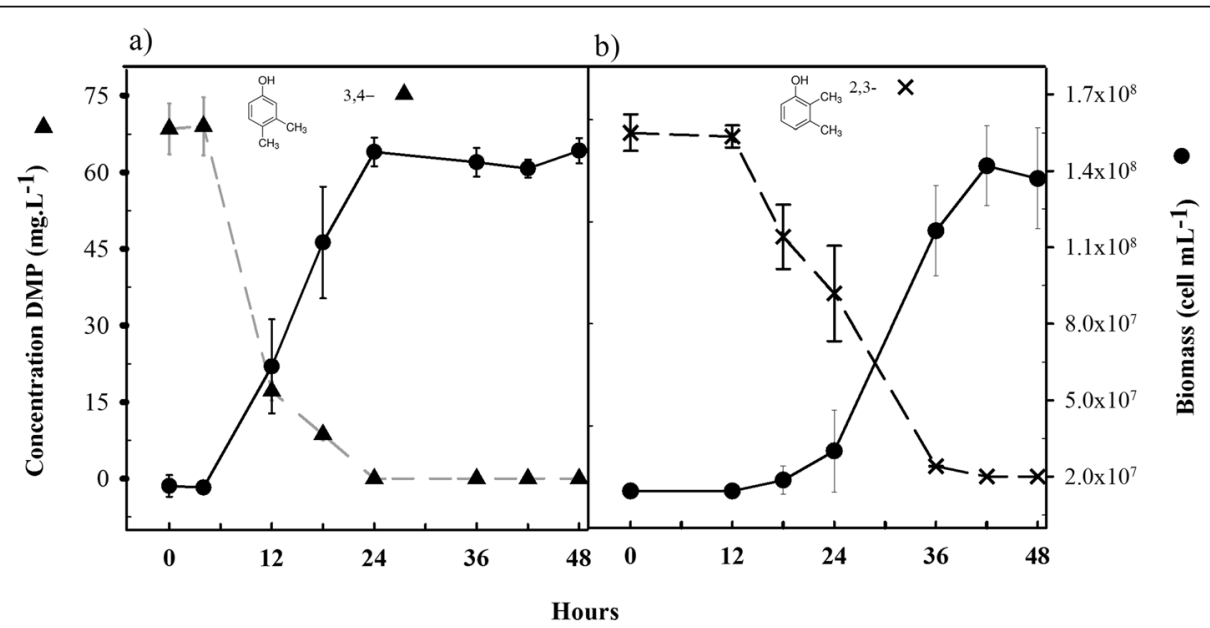

Fig. 1 Growth (circle) of Delftia sp. LCW and degradation of a 3,4-DMP (triangle) and b 2,3-DMP (cross) as sole carbon and energy source. Bars represent \pm SD 
Table 1 Yield coefficients and bacterial biomass for Delftia sp. LCW grown on DMP-isomers. The overall initial concentration of the DMP in all treatments was $70 \mathrm{mg} \mathrm{L}^{-1}$

\begin{tabular}{lll}
\hline DMP & $\begin{array}{l}\text { Maximal Biomass } \\
\left(\text { cell } \mathrm{mL}^{-1}\right)\end{array}$ & $\begin{array}{l}\text { Yield } \\
\left(\mathrm{mg} \text { dry weight } \mathrm{mg}^{-1} \mathrm{C}-\mathrm{DMP}\right)\end{array}$ \\
\hline $3,4-$ & $1.48 \times 10^{8} \pm 5.66 \times 10^{6}$ & $0.73 \pm 0.04$ \\
$2,3-$ & $1.42 \times 10^{8} \pm 1.56 \times 10^{8}$ & $0.69 \pm 0.62$ \\
$3,4-+2,3-$ & $1.49 \times 10^{8} \pm 1.27 \times 10^{7}$ & $0.73 \pm 0.07$ \\
$3,4-+3,5-$ & $7.88 \times 10^{7} \pm 4.10 \times 10^{6}$ & $0.28 \pm 0.04$ \\
$3,4-+2,5$ & $8.61 \times 10^{7} \pm 1.01 \times 10^{7}$ & $0.39 \pm 0.02$ \\
$3,4-+2,4$ & $6.48 \times 10^{7} \pm 1.54 \times 10^{7}$ & $0.35 \pm 0.02$ \\
$3,4-+2,6$ & $6.24 \times 10^{7} \pm 1.82 \times 10^{6}$ & $0.30 \pm 0.66$ \\
\hline
\end{tabular}

3,5-DMP were completely transformed (Fig. $2 \mathrm{~b}$ and c), whereas partial transformation of 2,4-DMP (Fig. 2d) and no transformation of 2,6-DMP were observed (Fig. 2e). The mixture of 3,4- and 2,3- DMP gave rise to a similar yield to the one obtained with 3,4-DMP alone (Table 1). Meanwhile, mixtures with 3,4- plus 3,5-, 2,5- or 2,4-DMP yielded approx. half of the bacterial yield (Table 1). In addition, bacterial biomass was significantly higher in the mixture of 3,4- and 2,3- DMP than the biomass of the other DMP mixtures $(p<0.001$, Additional file 1: Table A). Therefore, it was evident that none cell growth was giving by 3,5-, 2,5- and 2,4-DMP. No abiotic losses were detected in any DMP isomer solutions, proving that the decrease in DMP concentrations was due to microbial activity (data not shown).

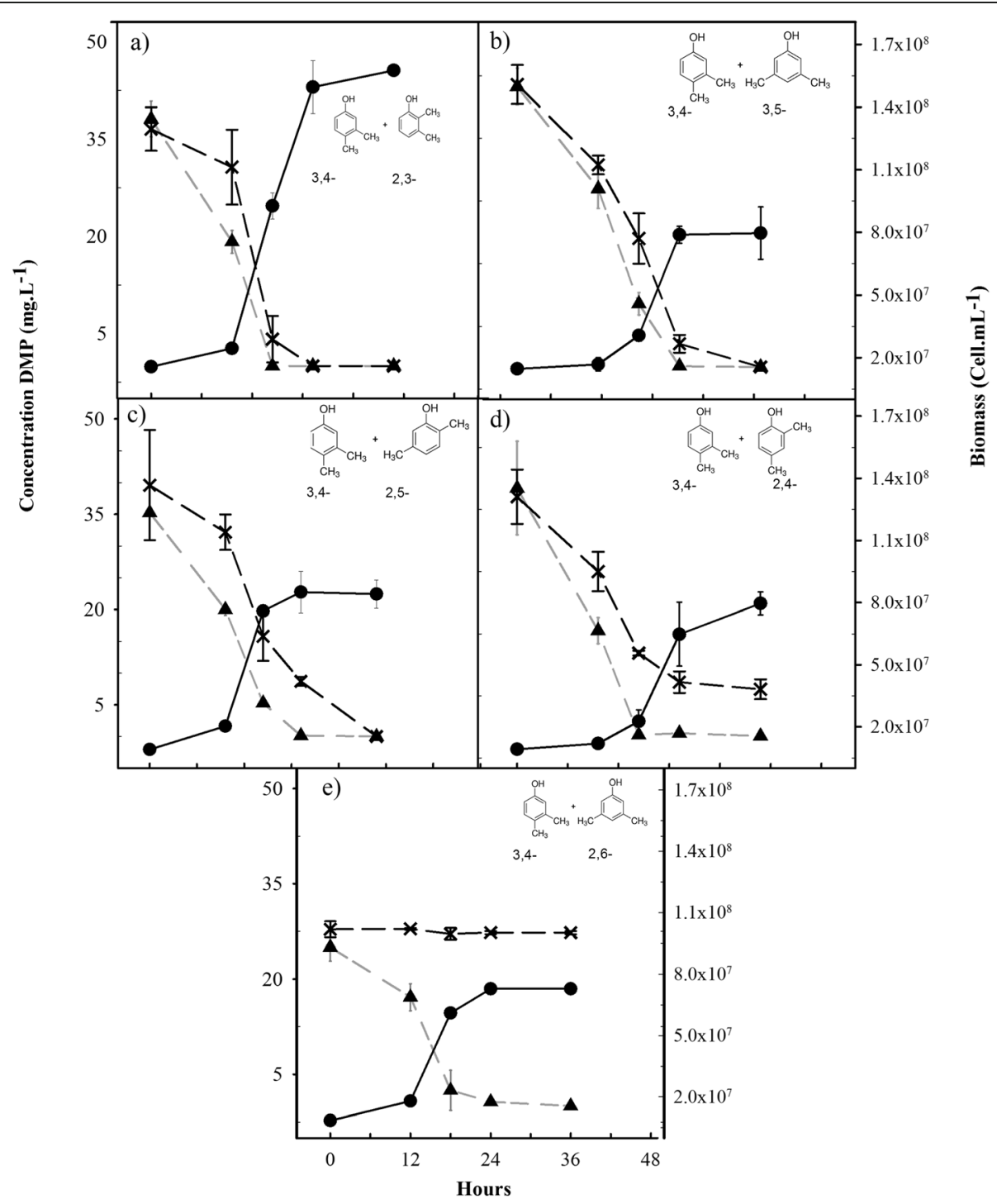

Fig. 2 Growth (circle) of Delftia sp. LCW and degradation of the isomeric mixtures. a 3,4-DMP (triangle) and 2,3-DMP (cross), b 3,4-DMP (triangle) with 3,5-DMP (cross), c 3,4-DMP (triangle) with 2,5-DMP (cross), d 3,4-DMP (triangle) with 2,4-DMP (cross), and e 3,4-DMP (triangle) with 2,6-DMP (cross). Bars represent $\pm \mathrm{SD}$ 
Detection of aerobic catabolic genes in Delftia sp. LCW

Among the different primer sets targeting catabolic genes tested with Delftia sp. LCW, amplification was only observed with phenol hydroxylase gene primers. The deduced protein sequence had a length of 214 amino-acids and the most closely related identified protein was the phenol hydroxylase large subunit from Delftia sp. AZ1-13 (ACZ44761). The protein clustered with phenol hydroxylases of Comamonas testosteroni TA441 (BAA34172) and other members of the family Comamonacea, as well as some few toluene monooxygenases of Burkholderia cepacea (stain JS150-AAG40791 and strain G4-AAL50373) (Fig. 3). It was not possible to detect amplification of other BTEX catabolic genes with the set of primers used.

\section{Growth of Delftia sp LCW. on other aromatics}

D. acidovorans grew on $30 \mathrm{mg} \mathrm{L}^{-1}$ benzene to a biomass of $7.44 \times 10^{7} \pm 1.46 \times 10$ cell x mL within $48 \mathrm{~h}$. Growth of the strain on other BTEX compounds was not observed.

\section{Proteomic analysis}

The label-free shotgun proteomics approach allowed the identification of 1814 proteins (Additional file 2). First, an unsupervised clustering approach (Principal Component Analysis, PCA) based on the different treatments, revealed clear segregation by sample treatment. The variances among the treatment groups showed that replicate analyses are clustering together. The PCA analysis also showed a greater segregation between the proteome profile of 3,4-DMP and 2,3-DMP among the four treatments (Additional file 3 ). The proteins that were significantly different between 3,4- and 2,3-DMP, were functionally assigned according to KO (KEEG Orthology), which characterizes gene functions in order to infer high level protein functions of the organism.. The main functional categories of the proteins that differed between 3,4- and 2,3-DMP treatments can be found in Additional file 4.

In total, five proteins related with aromatic degradation pathways could be identified (Table 2). Phenol hydroxylase, catechol 2,3-dioxygenase, 2-hydroxymuconic-semialdehyde dehydrogenase and 4-oxalocronate tautomerase were identified in all treatments. Protocatechuate 4,5-dioxygenase was identified only in 2,3-DMP grown cells. In Fig. 4, the protein abundance of related DMP proteins present in 2,3and 3,4-DMP as singles isomers are indicated. There were not significant differences of the abundances of the proteins between for 2,3- and 3,4-DMP treatments, for any of the proteins related with aromatic degradation (phenol hydroxylase, $p=0.160$; catechol 2,3-dioxygenase, $p=0.227$, 2-hydroxymuconic semialdehyde dehydrogenase, $p=0.488$ and 4-oxalocronate tautomerase $p=0.227$ ) (Additional file 1: Table B).

\section{Toxicity of DMP-isomers to Delftia sp. LCW}

Pearson correlation coefficient between $\mathrm{EC}_{50}$ and the log $\mathrm{P}_{\text {ow }}$ showed a negative correlation for all DMPs-isomers (correlation coefficient -0.978 and $p$-value $=0.0007$ ). Hence, 3,5-DMP (represented by the highest $\log \mathrm{P}_{\mathrm{ow}}$ ) had the lowest $\mathrm{EC}_{50}$ value, followed by 2,4-, 2,3-, 2,6-, 2, 5- and 3,4-DMP (Fig. 5).

\section{Discussion}

Based on the best performance to degrade DMP among the obtained isolates, the strain named as Delftia sp. LCW was selected. This isolate proved to be a close relative of the type strain Delftia sp. SM-1 and several strains of Delftia acidovorans. Strains of D. acidovorans, formerly known as Comamonas acidovorans [17], have been reported as degraders of 4-nitrobenzoate [18], 2,4-dichlorophenoxyacetic acid (2,4-D) and 4-chloro-2-methylphenoxyacetic acid (MPCA) [19]. Other isolates from the genus Delftia are able to degrade a wide range of phenoxyalkanoic acid herbicides, chlorinated phenols [20-22], sodium dodecyl sulfate [23], phenanthrene [24] and taurocholate [25]. Another family related bacterium, Comamonas testosteroni CNB-2 has been also reported to degrade 4-chlorophenol (4-CP), phenol and methylphenols [26, 27]. However, to our knowledge this is the first report of a Delftia strain able to degrade DMP and benzene.

Delftia sp. LCW was able to grow on the ortho-DMP isomers as a sole carbon and energy source. A similar growth profile has previously reported for Cupriavidus pinatobuensis JMP 134 [28], Pseudomonas CF600 [10, 29], Pseudomonas aeruginosa T1 [30] and Comamonas testosteroni JH5 [26].

In general, DMP biodegradation have been reported for all isomers, mainly through four different pathways, 1) monooxygenation of the aromatic ring to form dimethylcatechols followed by extradiol ring-cleavage as reported for 2,3- and 3,4-DMP degradation [28, 31], 2) oxidation of the methylsubstituent to form methyl-substituted gentisates followed by degradation through a gentisate degradative pathway as reported for 2,5-, and 3,5-DMP degradation [32, 33]; 3) oxidation of both methylsubstituents to form 4-hydroxyisophthalate followed by hydroxylation and degradation via a protocatechuate pathway as reported for 2,4-DMP degradation $[34,35]$ or 4) two successive monooxygenation of the aromatic ring 2,6-dimethylhydroquinone and 2,6-dimethyl-3-hydroxyhydroquinone as reported for 2,6-DMP degradation [11]. Proteome analysis showed the expression of a catechol meta cleavage pathway by Delftia sp. LCW in the presence of 3,4-DMP and 2,3-DMP including a catechol 2,3-dioxygenase, a 2-hydroxymuconic semialdehyde dehydrogenase and a 4-oxalocronate tautomerase. Catechols will be formed by a phenol monooxygenase, where the gene encoding the alpha-subunit (P3 subunit) was also detected in the genome through PCR, in 


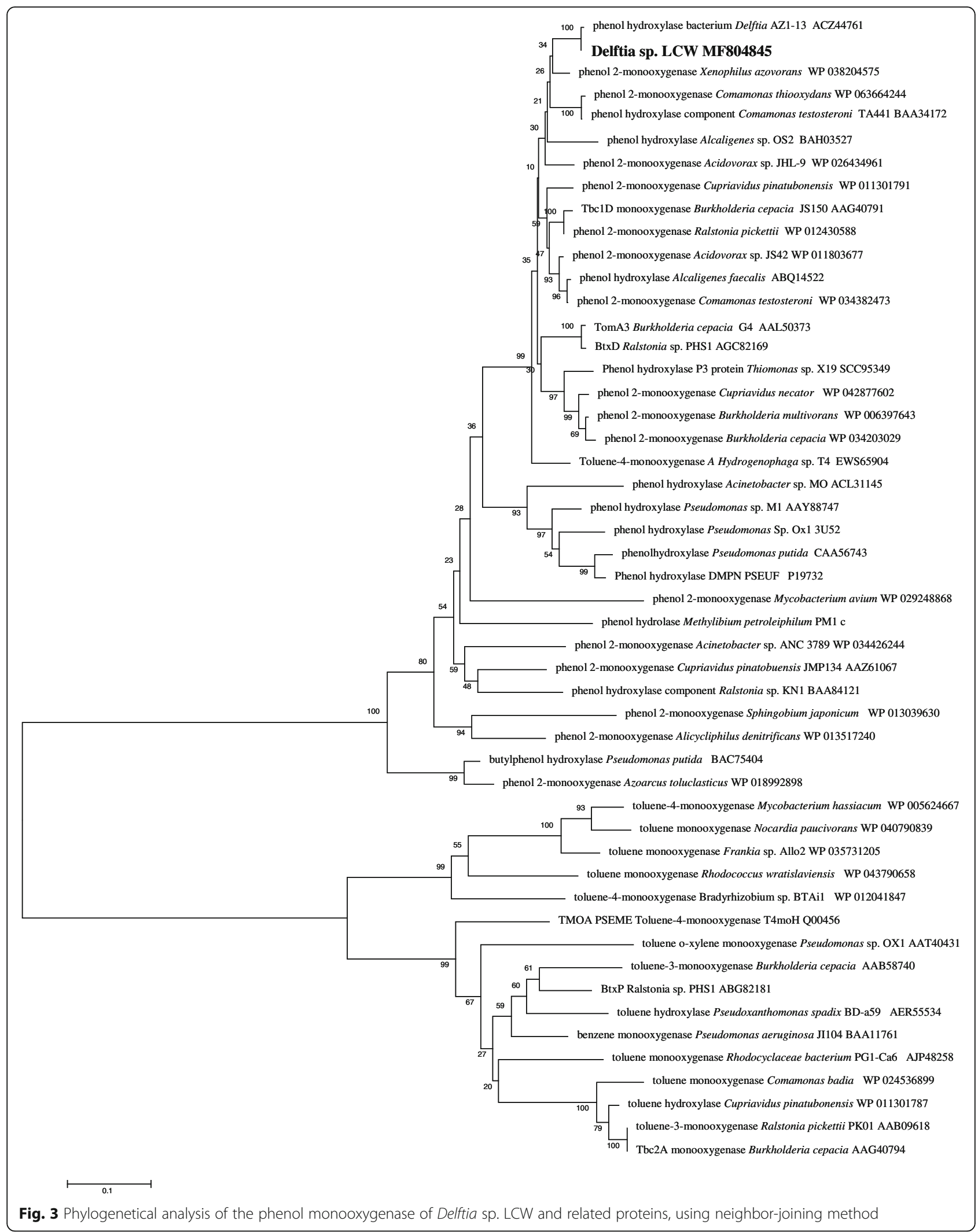


Table 2 Identified proteins of Delftia sp. involved in phenol catabolic pathways

\begin{tabular}{|c|c|c|c|c|c|c|}
\hline Treatment & Entry & Protein names & Gene names & Organism & Peptide length (bp) & $\begin{array}{l}\text { Inferred DMP -catabolic } \\
\text { pathway }\end{array}$ \\
\hline $\begin{array}{l}3,4-, 2,3-\text { and } \\
\text { mixtures }\end{array}$ & D1LCK1 & $\begin{array}{l}\text { Phenol hydroxylase } \\
\text { large subunit }\end{array}$ & & Bacterium AZ1-13 & 186 & $\begin{array}{l}\text { Catechol meta } \\
\text { and ortho cleavage }\end{array}$ \\
\hline $\begin{array}{l}3,4-2,3-\text { and } \\
\text { mixtures }\end{array}$ & Q60GE8 & $\begin{array}{l}\text { Catechol } \\
\text { 2,3-dioxygenase }\end{array}$ & ORF7NH & Delftia acidovorans & 314 & Catechol meta cleavage \\
\hline 2,3- & A9COK2 & $\begin{array}{l}\text { Protocatechuate } \\
4,5 \text {-dioxygenase }\end{array}$ & Daci_4445 & $\begin{array}{l}\text { Delftia acidovorans } \\
\text { (strain DSM } 14801 \text { / SPH-1) }\end{array}$ & 289 & $\begin{array}{l}\text { Protocatechuate } \\
\text { meta cleavage }\end{array}$ \\
\hline $\begin{array}{l}\text { 3,4-, 2,3- and } \\
\text { mixtures }\end{array}$ & Q8KRR9 & $\begin{array}{l}\text { 2-hydroxymuconic } \\
\text { semialdehyde } \\
\text { dehydrogenase }\end{array}$ & nahl & Pseudomonas fluorescens & 486 & Catechol meta cleavage \\
\hline $\begin{array}{l}\text { 3,4-, } 2,3-\text { and } \\
\text { mixtures }\end{array}$ & A0A1C7L505 & $\begin{array}{l}\text { 4-oxalocrotonate } \\
\text { toutomerase }\end{array}$ & ACM14_28930 & Delftia sp. JD2 & 138 & Catechol meta cleavage \\
\hline
\end{tabular}

order to produce the corresponding dimethylcatechol. A respective pathway for the degradation of 3,4-DMP was previously observed in Pseudomonas sp. CF600 and Pseudomonas putida. P35X [10, 31, 36].

Although catechol meta cleavage enzymes were detected in the presence of 2,3-DMP, an additional enzyme was identified when the isomer was provided as sole carbon source. This enzyme was the protocatechuate 4,5-dioxygenase (A9C0K2). Other proteins belonging to the protocatechuate pathway were not detected in the proteomic analysis. The protocatechuate pathway has been described only in 2,4-DMP degradation by Pseudomonas putida NCBIMB 9866 where it is formed through the subsequent oxidations both methyl group of 2,4-xylenol to form 4-hydroxyisophthalate and hydroxylation to protocatechuate [35]. Our results indicate that Delftia sp. LCW produced enzymes of the protocatechuate pathway in the presence of 2,3-DMP provided as a sole

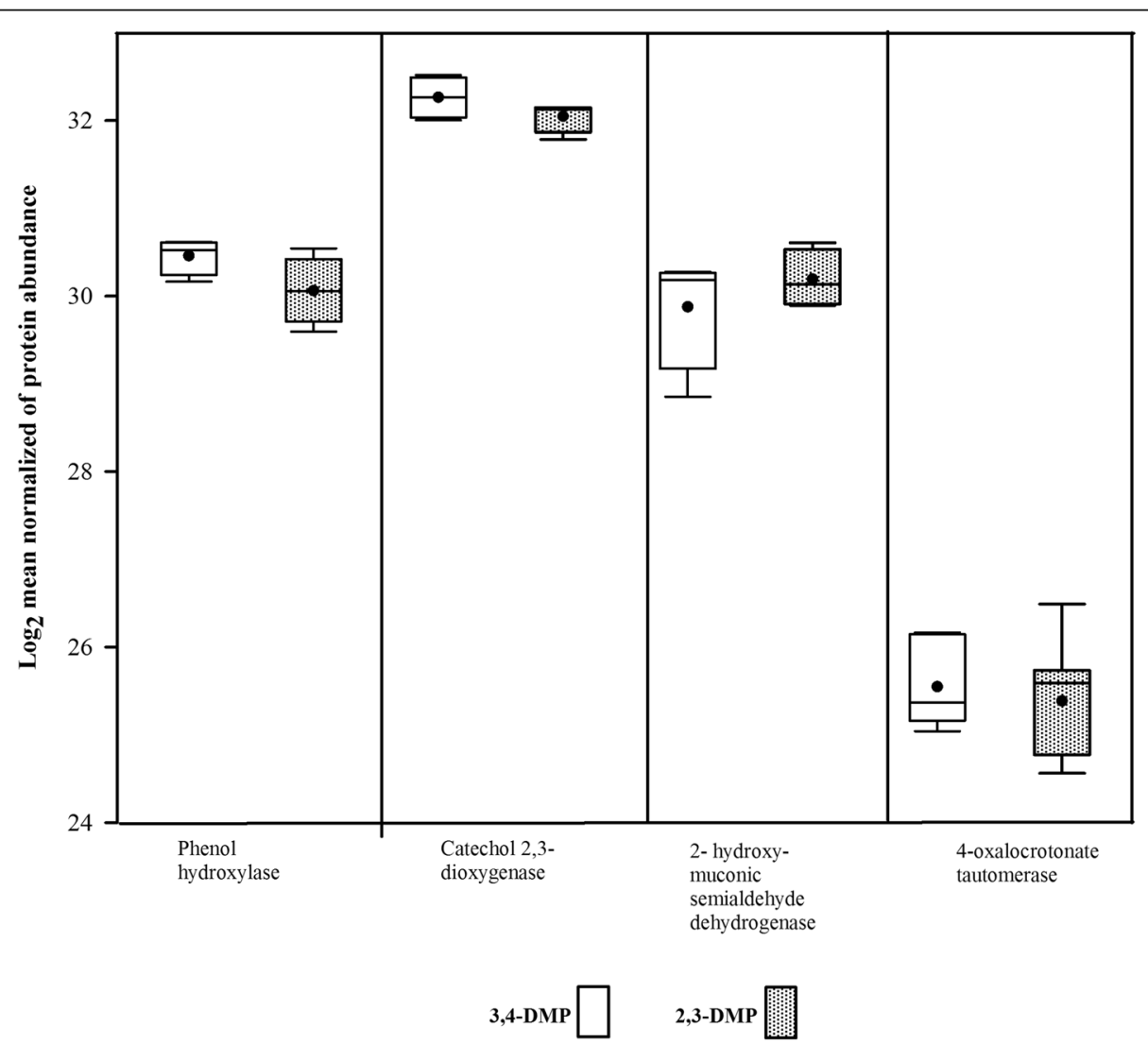

Fig. 4 Abundance of representative proteins involved in DMP degradation with 3,4- and 2,3-DMP as singles isomers. Bars indicate mean \pm SD. No statistical differences were found $(p>0.05)$ 


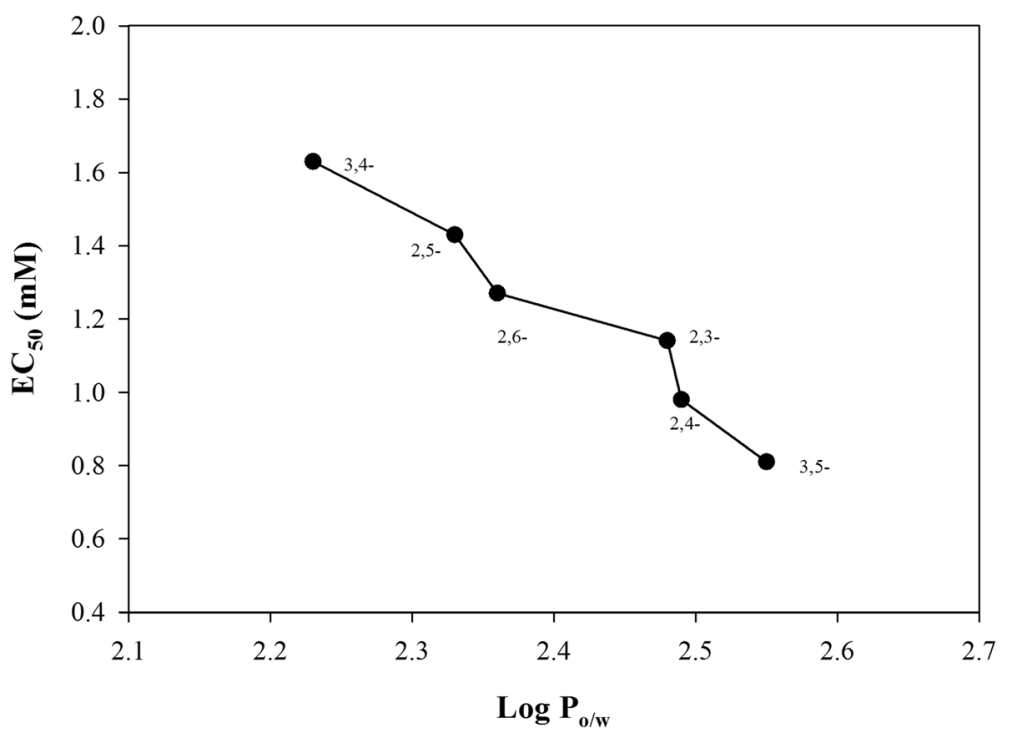

Fig. 5 Correlation between $\mathrm{EC}_{50}$ (half maximal effective concentration) and Log $\mathrm{P}_{\text {ow }}$ (partition coefficient octanol/water) for the six DMP-isomers

carbon source. However, this is probably due to fortuitous induction. Since proteins were identified by searching against UNIPROT database for genera related to Delftia or reported DMP-degrading bacteria, only the anticipated proteins listed could be identified.

When a mixture of 3,4- and 2,3-DMP was provided, there was an evident shorter lag phase for the degradation of 2,3-DMP. Fostered degradation of DMP in mixtures with other aromatic compounds was previously observed in a sequencing batch reactor, where degradation kinetics of 3,4-DMP were improved in the presence of 4-nitrophenol (4-NP) [12]. Likewise, experiments with C. testosteroni had shown that the addition of phenol increased cell growth and shortened the time necessary for 4-Clorophenol (CP) degradation [27]. Similar experiments with Pseudomonas putida XQ23 showed acceleration of 2,3-DMP degradation in the presence of DMP mixtures [37]. Those finding, in addition to higher abundance of meta pathway proteins in the mixture of the ortho DMP, suggested that the presence of 3,4-DMP in the mixture induced the expression of the catechol meta cleavage pathway and fostered the degradation 2,3-DMP.

Strain LCW was not able to grow on any of the other DMP isomers as a single substrate. Methylated phenols with methyl groups in ring position five $(2,5$ and 3,5-DMP), have been reported to be degraded by bacteria via gentisate pathway metabolism [32]. Proteins related to gentisate pathways were not detected in Delftia sp. LCW. Members of Delftia genus typically encode gentisate pathway. However, the appropriate methylhydroxylase has not been found in Delftia genomes, according to the search in PATRIC database. LCW strain transformed 2,4-, 2,5- and 3,5-DMP in the presence of
3,4-DMP. Mixtures of 3,4- and 2,3- DMP led to higher microbial yields than mixtures with 3,4- plus 3,5-, 2,5or 2,4-DMP, showing the ability of Delftia sp. LCW to use only 3,4- and 2,3-DMP as a carbon source, and to remove 3,5-, 2,5- and 2,4-DMP by co-metabolic transformation. Similar co-metabolic transformation of 2,4-, 3,4and 3,5-DMP has been reported for different strains of Pseudomonas [9] and C. testosteroni CPW301 [27]. It was also reported that $C$. testosteroni CPW301 was able to partially degrade 2,5- and 3,5- DMP by co-metabolism when growing with 4-CP and 4-MP [26]. In the case of Delftia sp. LCW, 3,4-DMP induced the enzymatic activity that allowed the transformation of 2,4-; 2,5- and 3,5-DMP and fostered 2,3-DMP degradation.

Screening of catabolic genes using degenerated primers and PCR led to the detection of the fragment of the phenol hydroxylase large subunit $[38,39]$. The phenol hydroxylases comprise related family of enzymes capable to hydroxylate mainly phenols and their methyl-substituted derivatives to the corresponding catechols $[40,41]$. Some phenol hydroxylases families have showed also the ability to transform toluene or benzene [42]. Phylogenetical relationships of phenol hydroxylase from LCW, showed that the closest protein is phenol hydroxylases from Delftia AZ1-13 (ACZ44761), which phenotype (L6) was a representative in a lab-scale reactor treating phenols [43]. Phylogenetical clustering of the phenol hydroxylase of LCW revealed similarities with the phenol hydroxylase Comamonas testosteroni TA441 (BAA34172) [44]. It was also similar to other strains with reported genes for catechol meta cleavage pathway e.g. Cupriavidus pinatubonensis [28, 45]. Another related phenol hydroxylase of LCW, belonging to 
Pseudomonas sp. M1 (ABM96259) with high similarities to the dmpKLMNOP hydroxylase gen of CF600 [46] .

In general, the catabolic pathway of 3,4- and 2,3- DMP by Delftia sp. LCW is similar to the one previously reported for Cupriavidus pinatobuensis JMP 134 [28], Pseudomonas sp. CF600 and Pseudomonas putida P35X [10, 29], Pseudomonas aeruginosa T1 [30] and Comamonas testosteroni JH5 [26]. Furthermore, phenol hydroxylases are reported to be of broad substrate specificity and to transform, phenol, 2-methylphenols, 2,4 and 3,4-DMP, $o$-cresol, $m$-cresol [28, 40, 47, 48], and are able to transform 2,4-DMP and 2,5-DMP [47]. Based on our findings, it is assumed that phenol hydroxylase of Delftia sp. LCW is not only responsible for the initial degradation of 2,3- and 3,4-DMP, but when induced by the presence of 3,4-DMP, it would be also able to transform other non-growth DMP isomers.

Delftia sp. LCW was also able to use benzene as growth substrate. One known pathway for the degradation of benzene involves two successive monooxygenations that are catalyzed by different soluble diiron monooxygenases [45]. Nevertheless, some phenol monooxygenases may catalyze both successive monooxygenations [40]. This characteristic was found in Pseudomonas sp. M1, where the multicomponent hydroxylase phc gene was responsible for the initial oxidation of phenol or benzene [46], this subunit is indeed similar to the one found in LCW. In addition, the phenol hydroxylase gene large subunit sequence found in LCW showed similarities with the toluene/benzene/chlorobenzene-monooxygenase (tbc1D) from Burkholderia sp. strain JS150 (AAG40791). Considering the detection of this gene sequence, the corresponding protein expressed and the phylogenetic similarities with other well-characterized functional proteins, we can propose that this phenol hydroxylase detected in Delftia sp. LCW may be responsible of catalyzing both monooxygenation reactions during the degradation of benzene.

Previous toxicity assays performed in bacterial strains such as Vibrio fischeri, showed highest toxicity of 3,4-DMP compared to other DMP-isomers, cresols, resorcinol and other dihydroxyphenols $[4,49,50]$. 3,4- and 2,3-DMP from activated sludge treating phenols-like wastewater had been reported to be toxic for eukaryotic multicellular organisms such as the ecotoxicological indicators Daphnia magna and Thamnocephalus platyurus [4]. In bacteria, there are cultures of Pseudomonas strains where the highest concentration of 3,4-DMP supporting growth was in the range of $2.5 \mathrm{mM}$ [51], i.e. similar to the current findings with Delftia sp. LCW. The toxicity tests of the different DMP isomers on Delftia sp. LCW showed that 3,5-DMP was the most toxic isomer followed by a decreasingly toxic series in the following order: 2,4-, 2,3-, 2,6-, 2,5- and 3,4-DMP (Fig. 5).

Considering that only 3,4-DMP contributed to $8.5 \%$ for the phenol toxicity in ash heap water from an oil shale industry [52] and given the fact that this isomer can impair the performance of biological treatment processes of phenolic wastewater [4], the tolerance and degradation of 3,4-DMP by Delftia sp. LCW, together with its role for co-metabolic transformation of other DMP isomers support the proposal of LCW strain as a promising microbial tool component on further developments of wastewater treatment technologies of phenolic compounds.

\section{Conclusions}

LCW strain was able to degraded complex aromatics compounds. DMPs and benzene are reported for the first time to be degraded by a member of Delftia genus. In this strain, the isomer 3,4-DMP acted as an inducer of phenol hydroxylase enzyme, that is responsible for a first oxidation of the DMPs, and it is followed by a further meta cleavage pathway for ortho-DMPs isomers. Such induction also led to the transformation of 2,4-, 2,5- and 3,5-DMPs. The higher resistance to DMP toxicity, and the understanding of degradation pathways for DMPs by LCW strain, as well as its origin as a rhizosphere bacterium from CWs, make of Delftia sp. LCW a suitable candidate to be used in bioremediation of coke-coal contaminated sites and is important to establish technological alternatives for wastewater treatment for coal-coke industry effluents.

\section{Methods}

Isolation and identification of DMP degrading bacteria

Bacterial strains were isolated by selective enrichment from a pilot-scale horizontal sub-surface $\mathrm{CW}$ fed with groundwater with benzene, phenols and $m$-cresols. In order to select strains with potential ability to degrade DMP for subsequent assays, bacterial growth on each of the six single isomers of DMP as a sole carbon source and energy was determined. The 16S rRNA gene from the only isolate showing growth on DMP isomers and called strain LCW, was amplified by PCR using universal bacterial primers 27F and 1492R [53]. Sanger sequencing of the purified PCR product was obtained (GATC Biotech AG, Cologne, Germany) and the $16 \mathrm{~S}$ rRNA gene sequence was compared to public databases using RDP [54] to identify closest reference sequences The $16 \mathrm{~S}$ rRNA gene sequence from strain LCW is available in KY643688k with accession number KY643688 [55].

\section{DMP degradation and co-metabolism assays}

In order to evaluate degradation and co-metabolic capabilities of the isolated, pure cultures of the strain were transferred from plates to liquid LB medium and incubated overnight at $30{ }^{\circ} \mathrm{C}$ with agitation. Then, cells were harvested by centrifugation, washed three times with phosphate buffer $\left(50 \mathrm{mM}\right.$ of $\mathrm{NaH}_{2} \mathrm{PO}_{4}, \mathrm{pH} 7.0$ ) and re-suspended in $50 \mathrm{~mL}$ of liquid M9 [56] (turbidity of 
0.05 at $620 \mathrm{~nm}$ ) with the corresponding carbon source (as described below). First, the selected isolate was grown on 3,4-DMP and 2,3-DMP separately with a concentration of $70 \mathrm{mg} \mathrm{L}^{-1}$ each. In addition, co-metabolic transformation by the strain was tested using each isomer (2,3-, 2,4-, 2,5-, 2,6- and 3,5-DMP) mixed with 3,4-DMP in concentrations of $35 \mathrm{mg} \mathrm{L}^{-1}$ per isomer (i.e. $70 \mathrm{mg} \mathrm{L}^{-1}$ DMP in total). Each treatment was set up in triplicates. Samples were taken from each culture every 4 and $12 \mathrm{~h}$ to determine cell number and DMP concentration, until the stationary phase was reached. Growth was followed by cell counting using a Coulter Counter ${ }^{\circ}$ (Beckman Coulter Inc) and the software Multisizer 3 Version $3.51^{\circ}$ (Beckman Coulter Inc.). The concentration of DMP in the cultures was measured in cell free supernatants by HPLC (Promicence, Shimadzu) equipped with a UV detector and a $2.7 \mu \mathrm{m}$ by $3.0 \times 150 \mathrm{~mm}$ poroshell 120 EC-C18 column (Agilent Technologies, USA). For the separation of the DMP isomers, the mobile phase A consisted of formic acid (0.1\%) and phase B consisted of acetonitrile (100\%), using the following gradients over a total run time of $45 \mathrm{~min}: 20 \%$ B to $40 \%$ B

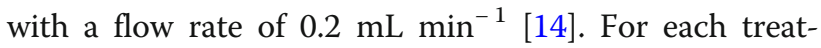
ment, a flask prepared under the same conditions without bacterial inoculum was set up in order to determine abiotic losses. In order to compare differences in degradation, the approximate bacterial yield for each mixture was calculated according to the following formula:

$$
\text { Yield }=\frac{\text { Increase in bacterial biomass }\left(m g \text { dry biomass. } m L^{-1}\right)}{C \text { from DMP consumed }\left(m g \cdot m L^{-1}\right)}
$$

\section{Increase in bacterial biomass $=$}

$$
\frac{\left(C_{t f} \text { cell. } m L^{-1}-C_{t 0} \text { cell. } m L^{-1}\right) \times 3 m g . m L^{-1 *}}{1 \times 10^{7} \text { cell. } m L^{-1}} \text { where, }
$$

$C_{t f}=$ number of cells per $\mathrm{mL}$ at the end of the expontial phase

$C_{t 0}=$ number of cells per $\mathrm{mL}$ at time cero

* A theoretical value of $3 \mathrm{mg} \mathrm{mL} \mathrm{m}^{-1}$ of dry mass equivalent to $1 \times 10^{7}$ cell $\mathrm{mL}^{-1}$ for Gram negative rod bacteria was calculated [57]

$C$ from $D M P$ consumed $=\left(\begin{array}{llll}D M P_{t 0} & m g . & m L^{-1}-\end{array}\right.$ $\left.D M P_{t f} m g . m L^{-1}\right) \times 0.787^{*}$ where,

$$
\begin{aligned}
D M P_{t 0} & =\text { Concentration of the corresponding DMP } \\
& \text { isomer at time cero } \\
D M P_{t f} & =\text { Concentration of the DMP isomer } \\
& \text { at the end of the expontial phase }
\end{aligned}
$$

*1 M of DMP contains $78.7 \%$ of carbon

\section{Growth of Delftia sp. LCW on other aromatic compounds} In order to investigate the spectrum of aromatics that Delftia sp. LCW was able to degrade, the strain was incubated with BTEX compounds. Initially, the strain was grown on LB and incubated overnight at $30{ }^{\circ} \mathrm{C}$ with agitation. Cells were harvested by centrifugation, washed three times with phosphate buffer [50 mM of $\mathrm{NaH}_{2} \mathrm{PO}_{4}$, (pH 7.0)] and re-suspended in $50 \mathrm{~mL}$ of $\mathrm{M} 9$ medium (turbidity of 0.05 at $620 \mathrm{~nm}$ ) and the selected sole carbon source at a concentration of $30 \mathrm{mg} \mathrm{L}^{-1}$. The growth tests were performed in duplicate. In addition, flasks prepared under the same conditions without carbon sources were tested as a negative control. Aliquots were taken for turbidity measurements at $620 \mathrm{~nm}$ every $12 \mathrm{~h}$ for 2 weeks.

\section{Detection and identification of aerobic catabolic genes in Delftia sp. LCW}

Delftia sp. LCW was assessed for the presence of catabolic genes potentially involved in aerobic degradation of aromatic compounds. Detection of monooxygenases [38, 39, 58], intradiol catechol dioxygenases [59] and extradiol catechol dioxygenases $[39,60]$ in the genome of strain LCW was performed by PCR using previously described degenerate primers (Additional file 5). The obtained PCR products were purified and sequenced (GATC Biotech AG, Cologne, Germany). The obtained nucleic acid sequences were translated and compared to entries in public databases [61]. The only detected gene sequence from this PCR specific target survey is available in GeneBank with accession number MF804845. Protein translation was obtained through EMBL-EBI translation tool service [62], where, frame 3 from the positive strand was chosen. PATRIC genome database [63] was used in order to check the detected gene in other related genus members.

\section{Proteomics analysis}

Protein extraction, LC-MS measurements and protein identification were performed as described previously by Lünsmann et al., [64]. Briefly, for protein extraction, cells were grown on 3,4- DMP and 2,3-DMP individually and on mixtures of 3,4- with 2,3- and 3,4- with 3,5-DMP as described before. Bacterial cells were harvested in the middle of the exponential phase. Lysis was achieved by ultrasonication and proteins were recovered by denaturation and solubilization with urea buffer. The protein lysates were applied on a polyacrylamide gel electrophoresis. Gel pieces were cut and the proteins were lysed using trypsin overnight. The resulting peptide lysates were separated by liquid chromatography hyphenated with mass spectrophotometry (LC-MS). For the identification of proteins, the acquired LC-MS data were searched against the public database UniprotKB using the closest related genera, i.e. Delftia, Pseudomonas, Ralstonia, Comamonas and bacterium AZ1-13, as inferred from the sequenced Phenol hydroxylase fragment. LC-MS spectra were searched using the Proteome Discoverer (Thermo Fisher Scientific, v1.4, San Jose, CA, USA). Search settings were: Sequest HT search engine, trypsin 
(full specific), MS tolerance $10 \mathrm{ppm}, \mathrm{MS} / \mathrm{MS}$ tolerance $0.02 \mathrm{Da}$, two missed cleavage sides, dynamic modifications oxidation (Met), static modifications carbamidomethylation (Cys). Only peptides that passed the FDR thresholds of < $1 \%$ FDR q-value (Percolator) and rank 1 peptides were considered for further analysis. Label-free quantification was done using the Top-3 peptide area for approach. These linear area values were $\log _{10}$-transformed, median normalized and furthermore missing value imputation were performed. Principal component analysis (PCA) was performed using InfernoRDN (version 1.6044.35184 July 19, 2016). Hypothesis significance tests were performed with Prostar [65] using the threshold of the log fold change (FC) of 1 and the threshold of $-\log$ ( $p$-value) of 2 for protein abundances. The proteins significantly differing between incubations with the 3,4- and 2,3-DMP were functionally assigned with the annotation tool KEGG BlastKOALA [66].

\section{Toxicity test}

Delftia sp. LCW was grown in mineral medium M9 with $4 \mathrm{~g} \mathrm{~L}^{-1}$ of disodium succinate as carbon and energy source in 50-mL flasks. Once the cultures reached the exponential phase of growth, DMP isomers were added separately at different concentrations (one flask per concentration) ranging from 45 to $350 \mathrm{mg} \mathrm{L}^{-1}$. No DMP isomers were added to the control culture. For each flask, the $\mathrm{OD}_{620 \mathrm{mn}}$ was measured every hour until the growth stopped in one of the cultures flasks. To determine the toxicity of each compound, specific growth rate $\mu\left(\mathrm{h}^{-1}\right)$, was calculated as follows [67]:

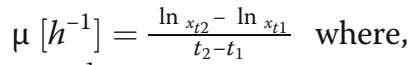

$\mu\left[h^{-1}\right]=$ Growth rate

$\mathrm{x}_{\mathrm{t} 1}=\mathrm{OD}_{620}$ at time $\mathrm{t}_{1}$

$\mathrm{x}_{\mathrm{t} 2}=\mathrm{OD}_{620}$ at time $\mathrm{t}_{2}$

$\mathrm{t}_{1}=$ one hour after toxin was added $[\mathrm{h}]$

$t_{2}=$ final time when the growth stopped [h]

Inhibited growth (\%) was defined as the percentages of the growth rates $\mu\left(\mathrm{h}^{-1}\right)$ of toxified cultures divided by the growth rate of the control culture. $\mathrm{EC}_{50}$ was calculated for each isomer by interpolation of the concentration resulting in $50 \%$ growth inhibition. Log $\mathrm{P}_{\text {ow }}$ values were obtained from Toxnet Database [68].

\section{Statistical analyses}

In order to indicate significant differences among values of maximal bacterial biomass in the cometabolic assay and protein abundances of selected proteins in proteomics data, normal distributions were tested with Shapiro Wilk and further parametric or not parametric test were performed accordingly. In addition, Pearson correlation was performed to correlate $\mathrm{EC}_{50}$ and $\log \mathrm{P}_{\mathrm{ow}}$ values for all isomers. Analyses were performed using SigmaPlot Version 13.0 ('Systat Sofware, Inc.). P-values and specific statistical tests are described in Additional file

\section{Additional files}

Additional file 1: Table A. $p$-values for the cometabolic assay, and Table B. p-values of paired t-tests for the comparison between 2,3- and 3,4-DMP. (DOCX 16 kb)

Additional file 2: Table S2. Proteome raw data for DMP treatments (XLSX 22980 kb)

Additional file 3: Figure S1. Principal component Analysis of the proteomic profile of strain LCW for the four DMP treatments. (PNG $37 \mathrm{~kb}$ )

Additional file 4: Figure S2. Proteins functional category of Delftia sp. LCW for the proteins with significant differences between 3,4- and 2,3DMP isomers (proteins with $p$-value $<0.001$ for FC were selected for the analysis). (TIF $100 \mathrm{~kb}$ )

Additional file 5: Table S1. Primers used for targeting catabolic genes in the genome of Delftia sp. LCW (DOCX 34 kb)

\section{Abbreviations}

BTEX: Benzene, toluene, ethylbenzene and xylenes; $\mathrm{CL}$ : Chlorophenol; COD: Chemical oxygen demand; CW(s): Constructed Wetland(s); DMP: Dimethylphenols; $\mathrm{EC}_{50}$ : Half maximal effective concentration; EMBLEBI: European Molecular Biology Laboratory-The European Bioinformatics Institute; FC: Fold change; FDR: False discovery rate; HPLC: High performance liquid chromatography; KEGG: Kyoto encyclopedia of genes and genomes; KO: KEGG orthology; LB: Lysogeny broth; LC-MS: Liquid chromatographymass spectrometry; LCW: Delftia sp. strain LCW; Log Pow: Partition coefficient octanol/water; MP: Methylphenol; NP: Nitrophenol; PATRIC: Pathosystems Resource Integration Center; PCA: Principal components analysis; RDP: The Ribosomal Database Project; UniprotKB: UniProt Knowledgebase

\section{Acknowledgements}

We thank Raúl Blázquez Arroyo, Marta Curiel Fernandez and Soeren Schmechta for the support during the isolation of the strain and preliminary tests. We thank Kathleen Eismann for the proteomics protocol performance. We thank the

Helmholtz Centre for Environmental Research-UFZ - Department of Environmental Biotechnology and Department of Molecular Systems Biology for financial support and infrastructure.

\section{Funding}

Mónica A. Vásquez--Piñeros thanks COLCIENCIAS Departamento de Ciencia, Tecnología e Innovación- República de Colombia (Convocatoria 568-Doctorados en el exterior) for a sustaining grant for Doctoral studies. The funding institution had no additional role in the design of the study, collection, analysis, interpretation of data, nor in writing the manuscript.

\section{Availability of data and materials}

The data that support the findings of this study are available from the corresponding author upon reasonable request.

\section{Authors' contributions}

MAVP conceived the study, isolated the strain, performed the experiments, performed data analysis, and wrote the manuscript with significant input from all authors. PMML helped with the isolation strategy, NJ performed proteomic protocols and helped with the analysis of proteomic data. DHP helped with the phylogenetical and proteomic analysis and interpretation. CAR participated in the growth and degradation experiments. $\mathrm{HH}$ and $\mathrm{H}$ helped to conceive the study. HJH conceive the study, participated with toxicity tests and draft the manuscript. All authors contributed, read and approved the final manuscript.

Ethics approval and consent to participate

This article does not contain any studies with human participants or animals.

Consent for publication

Not applicable

Competing interests

The authors declare that they have no competing interests. 


\section{Publisher's Note}

Springer Nature remains neutral with regard to jurisdictional claims in published maps and institutional affiliations.

\begin{abstract}
Author details
${ }^{1}$ Helmholtz Centre for Environmental Research - UFZ, Department of Environmental Biotechnology, Permoserstr. 15, Leipzig, Germany. ${ }^{2}$ Technical University of Denmark, Research Data Management - DTU Library, Lyngby, Denmark. ${ }^{3}$ Helmholtz Centre for Environmental Research - UFZ, Department of Molecular Systems Biology, Leipzig, Germany. ${ }^{4}$ Helmholtz Centre for Infection Research -HZI, Microbial Interaction and Processes Research Group, Braunschweig, Germany. ${ }^{5}$ Helmholtz Centre for Environmental Research UFZ, Department of Environmental Microbiology, Leipzig, Germany. ${ }^{6}$ Microbiomas Research Foundation, Bogotá, Colombia.
\end{abstract}

Received: 22 January 2018 Accepted: 30 August 2018

Published online: 06 September 2018

\section{References}

1. Ahmaruzzaman M, Sharma DK. Adsorption of phenols from wastewater. J Colloid Interface Sci. 2005;287(1):14-24.

2. Kahru A, Maloverjan A, Sillak H, Põllumaa L. The toxicity and fate of phenolic pollutants in the contaminated soils associated with the oil-shale industry. Environ Sci Pollut Res. 2002;9(1):27-33.

3. Autenrieth RL, Bonner JS, Akgerman A, Okaygun M, McCreary EM. Biodegradation of phenolic wastes. J Hazard Mater. 1991;28(1-2):29-53.

4. Kahru A, Põllumaa L, Reiman R, Rätsep A, Liiders M, Maloveryan A. The toxicity and biodegradability of eight main phenolic compounds characteristic to the oil-shale industry wastewaters: a test battery approach. Environ Toxicol. 2000;15(5):431-42.

5. Zhou S, Watanabe H, Wei C, Wang D, Zhou J, Tatarazako N, et al. Reduction in toxicity of coking wastewater to aquatic organisms by vertical tubular biological reactor. Ecotoxicol Environ Saf. 2015;115:217-22.

6. Veeresh GS, Kumar P, Mehrotra I. Treatment of phenol and cresols in upflow anaerobic sludge blanket (UASB) process: a review. Water Res. 2005;39(1):154-70.

7. Vazquez I, Rodriguez J, Maranon E, Castrillon L, Fernandez Y. Study of the aerobic biodegradation of coke wastewater in a two and three-step activated sludge process. J Hazard Mater. 2006;137(3):1681-8.

8. Hopper DJ, Kemp PD. Regulation of enzymes of the 3,5-xylenol-degradative pathway in Pseudomonas putida: evidence for a plasmid. J Bacteriol. 1980; 142(1):21-6.

9. Viggor S, Heinaru E, Loponen J, Merimaa M, Tenno T, Heinaru A Biodegradation of dimethylphenols by bacteria with different ring-cleavage pathways of phenolic compounds. Environ Sci Pollut Res Int. 2002;1:19-26.

10. $\mathrm{Ng} L C$, Shingler $V$, Sze CC, Poh CL. Cloning and sequences of the first eight genes of the chromosomally encoded (methyl) phenol degradation pathway from Pseudomonas putida P35X. Gene. 1994;151(1-2):29-36.

11. Ewers J, Rubio MA, Knackmuss HJ, Freier-Schroder D. Bacterial metabolism of 2,6-xylenol. Appl Environ Microbiol. 1989;55(11):2904-8.

12. Tomei MC, Annesini MC. Biodegradation of phenolic mixtures in a sequencing batch reactor. Environ Sci Pollut Res. 2008;15(3):188-95.

13. Jardinier N, Blake G, Mauchamp A, Merlin G. Design and performance of experimental constructed wetlands treating coke plant effluents. Water Sci Technol. 2001;44(11-12):485-91.

14. Schultze-Nobre L, Wiessner A, Wang D, Bartsch C, Kappelmeyer U, Paschke $\mathrm{H}$, et al. Removal of dimethylphenols from an artificial wastewater in a laboratory-scale wetland system planted with Juncus effusus. Ecol Engin. 2015:80:151-5

15. Vymazal J, Greenway M, Tonderski K, Brix H, Mander Ü. Constructed wetlands for wastewater treatment. In: Verhoeven JTA, Beltman B, Bobbink $R$, Whigham DF, editors. Wetlands and natural resource management. Berlin, Heidelberg: Springer Berlin Heidelberg; 2006. p. 69-96.

16. Faulwetter JL, Gagnon V, Sundberg C, Chazarenc F, Burr MD, Brisson J, et al. Microbial processes influencing performance of treatment wetlands: a review. Ecol Engin. 2009;35(6):987-1004

17. Wen A, Fegan M, Hayward C, Chakraborty S, Sly LI. Phylogenetic relationships among members of the Comamonadaceae, and description of Delftia acidovorans (den Dooren de Jong 1926 and Tamaoka et al. 1987) gen. nov., comb. nov. Int J Syst Evol Microbiol. 1999;49(Pt 2):567-76.
18. Groenewegen PE, Breeuwer P, van Helvoort JM, Langenhoff AA, de Vries FP, de Bont JAM. Novel degradative pathway of 4-nitrobenzoate in Comamonas acidovorans NBA-10. J Gen Microbiol. 1992;138(Pt 8):1599-605.

19. Hoffmann D, Müller RH, Kiesel B, Babel W. Isolation and characterization of an alkaliphilic bacterium capable of growing on 2,4dichlorophenoxyacetic acid and 4- chloro-2-methylphenoxyacetic acid. Acta Biotechnol. 1996;16(2-3):121-31.

20. Müller RH, Jorks S, Kleinsteuber $\mathrm{S}$, Babel W. Comamonas acidovorans strain MC1: a new isolate capable of degrading the chiral herbicides dichlorprop and mecoprop and the herbicides 2,4-D and MCPA. Microbiol Res. 1999; 154(3):241-6.

21. Zhang C, Kang Q, Wang X, Zilles JL, Müller RH, Werth CJ. Effects of porescale heterogeneity and transverse mixing on bacterial growth in porous media. Environ Sci Technol. 2010;44(8):3085-92.

22. González AJ, Gallego A, Gemini VL, Papalia M, Radice M, Gutkind G, et al. Degradation and detoxification of the herbicide 2,4-dichlorophenoxyacetic acid (2,4-D) by an indigenous Delftia sp. strain in batch and continuous systems. Int Biodeter Biodegr. 2012;66(1):8-13.

23. Yilmaz F, Icgen B. Characterization of SDS-degrading Delftia acidovorans and in situ monitoring of its temporal succession in SDS-contaminated surface waters. Environ Sci Pollut Res Int. 2014:21(12):7413-24.

24. Vacca DJ, Bleam WF, Hickey WJ. Isolation of soil bacteria adapted to degrade humic acid-sorbed phenanthrene. Appl Environ Microbiol. 2005;71(7):3797-805.

25. Rosch V, Denger K, Schleheck D, Smits TH, Cook AM. Different bacterial strategies to degrade taurocholate. Arch Microbiol. 2008;190(1):11-8.

26. Hollender J, Dott W, Hopp J. Regulation of chloro- and methylphenol degradation in Comamonas testosteroni JH5. Appl Environ Microbiol. 1994; 60(7):2330-8.

27. Bae HS, Lee JM, Kim YB, Lee S-T. Biodegradation of the mixtures of 4chlorophenol and phenol by Comamonas testosteroni CPW301. Biodegradation. 1996;7(6):463-9.

28. Pieper DH, Stadler-Fritzsche K, Knackmuss H, Timmis KN. Formation of dimethylmuconolactones from dimethylphenols by Alcaligenes eutrophus JMP 134. Appl Environ Microbiol. 1995:61(6):2159-65.

29. Bartilson M, Nordlund I, Shingler V. Location and organization of the dimethylphenol catabolic genes of Pseudomonas CF600. Mol Gen Genet. 1990;220(2):294-300

30. Ribbons DW. Specificity of monohydric phenol oxidations by meta cleavage pathways in Pseudomonas aeruginosa T1. Arch Microbiol. 1970;74(2):103-15.

31. Shingler V, Franklin FC, Tsuda M, Holroyd D, Bagdasarian M. Molecular analysis of a plasmid-encoded phenol hydroxylase from Pseudomonas CF600. J Gen Microbiol. 1989;135(5):1083-92.

32. Hopper DJ, Chapman PJ. Gentisic acid and its 3- and 4-methyl-substituted homologues as intermediates in the bacterial degradation of m-cresol, 3,5xylenol and 2,5-xylenol. Biochem J. 1971;122(1):19-28.

33. Pieper DH, Engesser KH, Knackmuss HJ. (+)-4-Carboxymethyl-2,4dimethylbut-2-en-4-olide as dead-end metabolite of 2,4dimethylphenoxyacetic acid or 2,4-dimethylphenol by Alcaligenes eutrophus JMP 134. Arch Microbiol. 1990;154(6):600-4.

34. Chen YF, Chao H, Zhou NY. The catabolism of 2,4-xylenol and p-cresol share the enzymes for the oxidation of para-methyl group in Pseudomonas putida NCIMB 9866. Appl Microbiol Biotechnol. 2014;98(3):1349-56.

35. Chao H-J, Chen Y-F, Fang T, Xu Y, Huang WE, Zhou N-Y. HipH catalyzes the hydroxylation of 4-hydroxyisophthalate to protocatechuate in 2,4-xylenol catabolism by Pseudomonas putida NCIMB 9866. Appl Environ Microbiol. 2016;82(2):724-31.

36. Shingler V, Powlowski J, Marklund U. Nucleotide sequence and functional analysis of the complete phenol/3,4-dimethylphenol catabolic pathway of Pseudomonas sp. strain CF600. J Bacteriol. 1992;174(3):711-24.

37. Xiao Z, Huo F, Huang Y, Zhu X, Lu JR. A novel 2,3-xylenol-utilizing Pseudomonas isolate capable of degrading multiple phenolic compounds. Bioresour Technol. 2012:104:59-64.

38. Martinez-Lavanchy PM, Chen Z, Lunsmann V, Marin-Cevada V, Vilchez-Vargas $\mathrm{R}$, Pieper $\mathrm{DH}$, et al. Microbial toluene removal in hypoxic model constructed wetlands occurs predominantly via the ring monooxygenation pathway. Appl Environ Microbiol. 2015:81(18):6241-52.

39. Hendrickx B, Junca H, Vosahlova J, Lindner A, Ruegg I, Bucheli-Witschel M, et al. Alternative primer sets for PCR detection of genotypes involved in bacterial aerobic BTEX degradation: distribution of the genes in BTEX degrading isolates and in subsurface soils of a BTEX contaminated industrial site. J Microbiol Methods. 2006;64(2):250-65. 
40. Pérez-Pantoja D, González B, Pieper DH. Aerobic degradation of aromatic hydrocarbons. In: Timmis KN, editor. Handbook of hydrocarbon and lipid microbiology. Berlin, Heidelberg: Springer Berlin Heidelberg; 2010. p. 799-837.

41. Leahy JG, Batchelor PJ, Morcomb SM. Evolution of the soluble diiron monooxygenases. FEMS Microbiol Rev. 2003;27(4):449-79.

42. Cafaro V, Izzo V, Scognamiglio R, Notomista E, Capasso P, Casbarra A, et al. Phenol hydroxylase and toluene/o-xylene monooxygenase from Pseudomonas stutzeri OX1: interplay between two enzymes. Appl Environ Microbiol. 2004;70(4):2211-9.

43. Basile LA, Erijman L. Maintenance of phenol hydroxylase genotypes at high diversity in bioreactors exposed to step increases in phenol loading. FEMS Microbiol Ecol. 2010;73(2):336-48.

44. Arai H, Akahira S, Ohishi T, Maeda M, Kudo T. Adaptation of Comamonas testosteroni TA441 to utilize phenol: organization and regulation of the genes involved in phenol degradation. Microbiology. 1998;144(Pt 10):2895-903.

45. Perez-Pantoja D, De la Iglesia R, Pieper DH, Gonzalez B. Metabolic reconstruction of aromatic compounds degradation from the genome of the amazing pollutant-degrading bacterium Cupriavidus necator JMP134. FEMS Microbiol Rev. 2008;32(5):736-94.

46. Santos PM, Sá-Correia I. Characterization of the unique organization and coregulation of a gene cluster required for phenol and benzene catabolism in Pseudomonas sp. M1. J Biotechnol. 2007;131(4):371-8.

47. Arenghi FLG, Barbieri P, Bertoni G, de Lorenzo V. New insights into the activation of o-xylene biodegradation in Pseudomonas stutzeri OX1 by pathway substrates. EMBO Rep. 2001;2(5):409-14.

48. Jeong JJ. 3- and 4-alkylphenol degradation pathway in Pseudomonas sp. strain KL28: genetic organization of the lap gene cluster and substrate specificities of phenol hydroxylase and catechol 2,3-dioxygenase. Microbiology. 2003;149(11):3265-77.

49. Kahru A, Kurvet M, Külm I. Toxicity of phenolic wastewater to luminescent bacteria photobacterium phosphoreum and activated sludges. Water Sci Technol. 1996;33(6):139-46.

50. Kahru A, Pollumaa L, Reiman R, Ratsep A. Predicting the toxicity of oil-shale industry wastewater by its phenolic composition. Altern Lab Anim. 1999; 27(3):359-66.

51. Kahru A, Reiman R, Rätsep A. The efficiency of different phenol-degrading bacteria and activated sludges in detoxification of phenolic leachates. Chemosphere. 1998;37(2):301-18.

52. Kahru A, Kurvet M, Kurvet I. The study of toxicological impact of different compounds in complex mixtures: a case study on ash-heap water. Rev Clin Pharmacol Pharmacokin. 1997;11(2-3):137-41.

53. Weisburg WG, Barns SM, Pelletier DA, Lane DJ. 16 S ribosomal DNA amplification for phylogenetic study. J Bacteriol. 1991;173(2):697-703.

54. RDP Naive Bayesian Classifier. [cited 10 November 2016]. Available from: http://rdp.cme.msu.edu/seqmatch/seqmatch_intro.jsp.

55. NCBI. National Center for Biotechnology Information Nucleotide. Delftia sp. strain LCW 165 ribosomal RNA gene, partial sequence. Available from: https://www.ncbi.nlm.nih.gov/nuccore/KY643688.

56. Sambrook J, Fritsch EF, Maniatis T. Molecular cloning: a laboratory manual: Cold Spring Harbor Laboratory; 1989.

57. Neumann G, Cornelissen S, van Breukelen F, Hunger S, Lippold H, Loffhagen $\mathrm{N}$, et al. Energetics and surface properties of Pseudomonas putida DOT-T1E in a two-phase fermentation system with 1-decanol as second phase. Appl Environ Microbiol. 2006;72(6):4232-8.

58. Baldwin BR, Nakatsu CH, Nies L. Detection and enumeration of aromatic oxygenase genes by multiplex and real-time PCR. Appl Environ Microbiol. 2003;69(6):3350-8

59. Sei K, Asano K, Tateishi N, Mori K, Ike M, Fujita M. Design of PCR primers and gene probes for the general detection of bacterial populations capable of degrading aromatic compounds via catechol cleavage pathways. J Biosci Bioeng. 1999;88(5):542-50.

60. Brennerova MV, Josefiova J, Brenner V, Pieper DH, Junca H. Metagenomics reveals diversity and abundance of meta-cleavage pathways in microbia communities from soil highly contaminated with jet fuel under air-sparging bioremediation. Environ Microbiol. 2009;11(9):2216-27.

61. NCBI. National Center for Biotechnology Information. [cited 5 February 2017 ]. Available from: https://blast.ncbi.nlm.nih.gov/Blast.cgi.

62. EMBL-EBI. [cited 12 April 2017]. Available from: http://www.ebi.ac.uk/Tools/st/

63. PATRIC. Pathosystems Resource Integration Center. [cited 23 September 2017]. Available from: https://www.patricbrc.org/.
64. Lünsmann V, Kappelmeyer U, Taubert A, Nijenhuis I, von Bergen M, Heipieper $\mathrm{HJ}$, et al. Aerobic toluene degraders in the rhizosphere of a constructed wetland model show diurnal polyhydroxyalkanoate metabolism. Appl Environ Microbiol. 2016;82(14):4126-32.

65. Wieczorek S, Combes F, Lazar C, Giai Gianetto Q, Gatto L, Dorffer A, et al. DAPAR \&amp; ProStaR: software to perform statistical analyses in quantitative discovery proteomics. Bioinformatics. 2017;33(1):135-6.

66. KEGG. Kyoto Encyclopedia of Genes and Genomes. KOALA Orthology And Links Annotation. [cited August 30 2017]. Available from: http:// www.kegg.jp/blastkoala/.

67. Heipieper HJ, Loffeld B, Keweloh H, de Bont JAM. The cis/trans isomerisation of unsaturated fatty acids in Pseudomonas putida S12: an indicator for environmental stress due to organic compounds. Chemosphere. 1995;30(6):1041-51.

68. Toxnet. Toxicology Data Network. U.S. National Libray of Medicine. [cited 2 December 2016]. Available from: https://chem.sis.nlm.nih.gov/chemidplus/.

\section{Ready to submit your research? Choose BMC and benefit from:}

- fast, convenient online submission

- thorough peer review by experienced researchers in your field

- rapid publication on acceptance

- support for research data, including large and complex data types

- gold Open Access which fosters wider collaboration and increased citations

- maximum visibility for your research: over $100 \mathrm{M}$ website views per year

At BMC, research is always in progress.

Learn more biomedcentral.com/submissions 